\title{
房総半島鹿野山周辺地域の斜面崩壊の地形・地質的特性
}

\section{Some Geological and Geomorphological Characteristics of the Slope Failures on the Mt. Kano-zan and its Environs in the Boso Peninsula, Japan}

\author{
古 谷 尊 彦*
}

Takahiko FURUYA
大 倉

Hiroshi OHOKURA

\begin{abstract}
The relationships between the differential erosion topography and the slope failures on the Mt. Kano-zan and its environs in the Boso peninsula, Japan have been discussed. The results are as follows.

The geology consists of sedimentary rock formations can divided into two types. First one is sandstone rich formation type and the other type is mudstone rich formation. The former area is formed high relief, low slope angle and low valley density. The later is formed low relief, high slope angle and high valley density. It is considered that the main facter is based on the low potential of erosion derived from decreasing surface stream which caused on permeability of unconsolidated sandstone.

The phenomena of slope failures are main agency of the processes beneath the surface layer on the mountain slope of the Kano-zan and its environs. The distribution of the slope failures are consolidated on the mountains which composed of low relief, high slope angle and valley density. This is very important phenomena of the main agency of the aifferetial erosion topography in the humid temperature area.
\end{abstract}

キーワード: 斜面崩壊, 組織地形, 鹿野山, 市宿層, 岩坂層

\section{1.はじめに}

千葉県の地形は, 洪積台地と沖積低地の占める割合が 約 $70 \%$, 残り $30 \%$ も部分高度 $300 \mathrm{~m}$ に満たず，丘陵の 範囲に入る地形である。この山地面積の少なさから, 当 然崩壊現象と最も関係の深い急傾斜地の分布面積も限ら れ, 千葉県は斜面崩壊現象とは無縁と考えられがちで あった。しかし, 現実には昭和 45 年 7 月県中〜南部に梅 雨前線による豪雨が発生し，これによる斜面崩壊・洪水 災害で死者 19 人を出す事態が発生した。次いで翌年の昭 和 46 年 9 月台風 25 号による豪雨では, 御宿・勝浦・大 原・長南など県南東部と八日市場・大栄・小見川・多古・ 芝山など北西部を中心に死者 56 人を数える崩壊災害に 発展した。また, 平成元年 8 月, 再び県中〜南部に, 前 線通過と台風の影響による集中豪雨の発生をみた。その 結果, 集中豪雨の中心となった県中〜南部地域では, 斜 面崩壊の多発と洪水とによって死者 4 人重軽傷者 9 人を 出す惨事となった。

このような集中豪雨に起因した崩壊災害のほか, 昭和 62 年 12 月に発生した千葉県東方沖地震によっても, 両 総台地東南端および長南町周辺の低い丘陵地帯の急崖斜

* 千葉大学教養部

** 科学技術庁防災科学技術研究所
面に崩壊が見られた。この崩壊の規模は，地震の最大震 度が 5 ，マグニチュードが 6.7 という規模であったこと もあって，比較的小さかった。しかし崖端部には崩壊に まで至らなかったが，新鮮な無数の亀裂の発生があった。

筆者は, これらの崩壊現象のうち, 豪雨によって発生 した鹿野山周辺地域の崩壊現象について, 地形・地質的 な調査を実施した。調査方法は空中写真判読と現地調查 による。空中写真は縮尺 $1 / 20,000$ の垂直写真で昭和 45 (1970) 年以前, 昭和 47 (1972) 年, 平成元 (1989.8.29) 年の各撮影年次の異なるものを使用し，各時期の異なる 崩壊地の分布も調べた。また，平成元年の崩壊災害につ いては千葉県撮影の斜め航空写真も参考にした。

\section{2. 鹿野山周辺地域の地質・地形}

\section{1 ）鹿野山・九十九谷地域の地質}

本地域の地質については $1 / 100,000$ の地質図『東京湾 とその周辺地域の地質』(1976), 日本油田・ガス田図 (1962)，三梨（1954）などがある。前者は千葉県下の東 京湾に面する地域が扱われており，後者は鹿野山南側斜 面から九十九谷地域の詳細な地域が示されている。これ らによると, 崩壊地調査地域は北から, 主に上総層群の 佐貫層の砂質泥岩, 長浜層の䃯岩および含碟砂岩, 市宿 層の粗粒砂岩および含碩砂岩, 岩坂層の泥質砂岩, 東日 


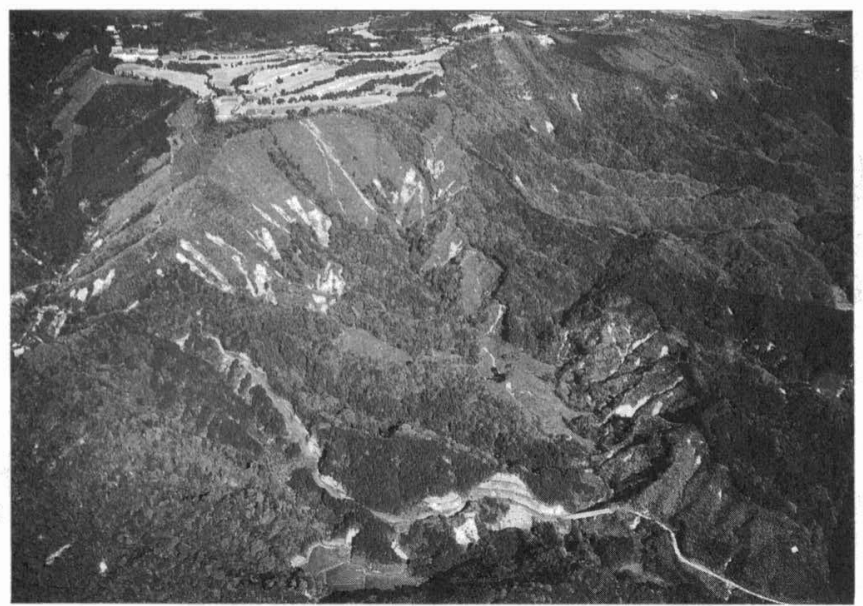

写真-1 苗割上空から北方鹿野山方面を望む(千葉県林務部撮影) 手前の低山地帯が九十九谷地区。後方の鹿野山南斜面の崩壊地は頭部 の高度がそろう傾向にあり,これは市宿層と岩坂層の境界付近に当 る。

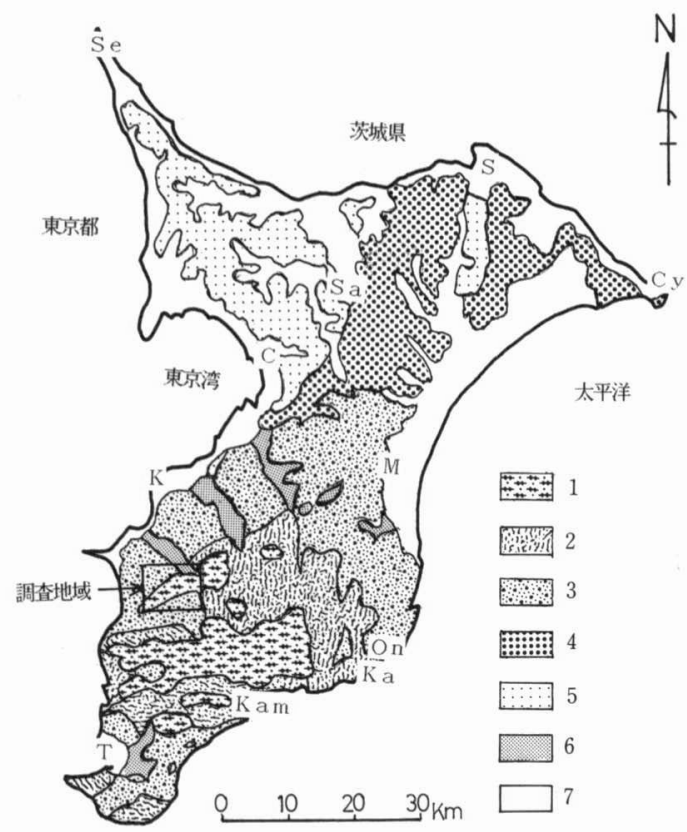

図-1 千葉県の地形の概要および調查位置 (1/20 千葉県土地 分類図, 1972; より簡略化)

$\mathrm{C}$ : 千葉, $\mathrm{K}$ : 木更津, $\mathrm{C}_{\mathrm{y}}$ : 銚子, $\mathrm{M}$ : 茂原, $\mathrm{O}_{\mathrm{n}}$ : 御 宿, $\mathrm{K}_{\mathrm{a}}$ : 勝浦, $\mathrm{K}_{\mathrm{an}}$ : 鴨川, $\mathrm{T}$ : 館山, $\mathrm{S}$ : 佐原, $\mathrm{S}_{\mathrm{a}}$ : 佐 倉, $\mathrm{S}_{\mathrm{e}}$ : 関宿, 1: 小起伏山地, 2: 大起伏丘陵, 3: 小起 伏丘陵, 4: 上位台地, 5: 下位台地, 6: 河成段丘, 7: 低 地

笠層の粗粒砂岩およぴ含䃯砂岩からなる。長浜層の砅岩 および含礫砂岩と, 市宿層の粗粒砂岩および含礫砂岩は, 未固結で透水性のよい地層を構成している。この地層群 の傾斜は北へ $10^{\circ}$ 以下で単斜する。しかし, 鹿野山では, これらの地層は大部分厚い火山灰層に被覆されている。
鹿野山の南斜面から九十九谷に広がる地 域は, 岩坂層のシルト層または泥質の砂岩 と粟倉層の砂質泥岩である。さらに, これ らの地層の南へ, 東日笠層の砂岩および含 䃯砂岩の分布が広がる。粟倉層は固結が進 み透水性は良くない。岩坂層・粟倉層は $10^{\circ}$ 以下で，ゆるく北へ傾斜するが，東日笠層 はこれに反して, $10^{\circ}$ 以下のゆるい傾斜で南 へ傾斜する。図一 2 には日本油田・ガス田図 (地質調査所, 1962)をコンパイルして示し た。

2) 鹿野山・九十九谷地域の地形

本地域の地形は, Nakagawa（1960）に よって報告された透水性の違いに基づく単 斜丘陵（カデナの地形）の地形である。こ の地形の概形を知るために, 接峰面図・切 谷面図を作成し，その図からさらに南北方 向の地形断面図を作成した図 $-3(\mathrm{a})$ 。この地形断面と平 行して $1 / 25,000$ 鬼泪山図幅から作成した地形断面, これ に写真判読と現地調査によって確認された平坦面・緩斜 面・遷急点を併記した図図ー3(b)を作成した。なお, 接峰 面図・切谷面図作成に当たっては, あらかじめこの地域 の成長曲線を描き, これから方眼の大きさ $2 \mathrm{~km}^{2}$ を求 め, その值を基に作成している。

こうして作成された図 $-3(\mathrm{a}, \mathrm{b})$ に示されている鹿 野山山塊の地形的特徵は以下のようになる。図ー3(a)に 示される接峰面と切谷面から作成した地形断面は, 両者 の仮想される山地の高度の中心軸が異なっている。接峰 面は現在の地形の起伏の大勢を示し, 切谷面は侵蝕基準 面の昇降を考慮しない場合に山地が侵蝕されて到達する であろうと仮想される起伏である。調查地域の土地の昇 降がないかあるいは無視しうると仮定して，この両者を 比較すると, 鹿野山山塊の地形の特徴は次のようにいえ る。鹿野山山塊の切谷面に示される山地の中心軸は, 明 らかに現在の山塊の起伏の中心軸より北に偏っており, この山塊の侵蝕ポテンシャルは南側斜面に大きいことを 示している。

現在の地形断面を示している図ー3(b)では, 低起伏で 平坦面・緩斜面・遷急点を伴う九十九谷地域と, 高起伏 で南側に急斜面を配し, 北側にゆるく起伏を減ずる鹿野 山山塊が示される。両地域とも, 平坦面・緩斜面・遷急 点の発達など, 動的平衡に到達する前の極めて侵食の旺 盛な地域であることを示している。この状況は土地分類 基本調査（川崎ほか，1976）の資料から当該地域を抜き 出して作成した図 -4 の傾斜分布図にもうかがえる。そ の特徵は鹿野山南斜面に沿って $30^{\circ}$ 以上の急傾斜面がほ ぼ東西に配列分布する。鹿野山の稜線部では $8^{\circ}$ 以下の傾 
斜が広範囲に広がり，極めて平坦である。しかし，部分 的には，マザー牧場北西部の梁く切り込んだ谷にそって
分布する 30 以上の急傾斜地や，馬登付近の $20^{\circ}$ を越える

傾斜の分布地域もある。鹿野山のこのような特徵に比べ,

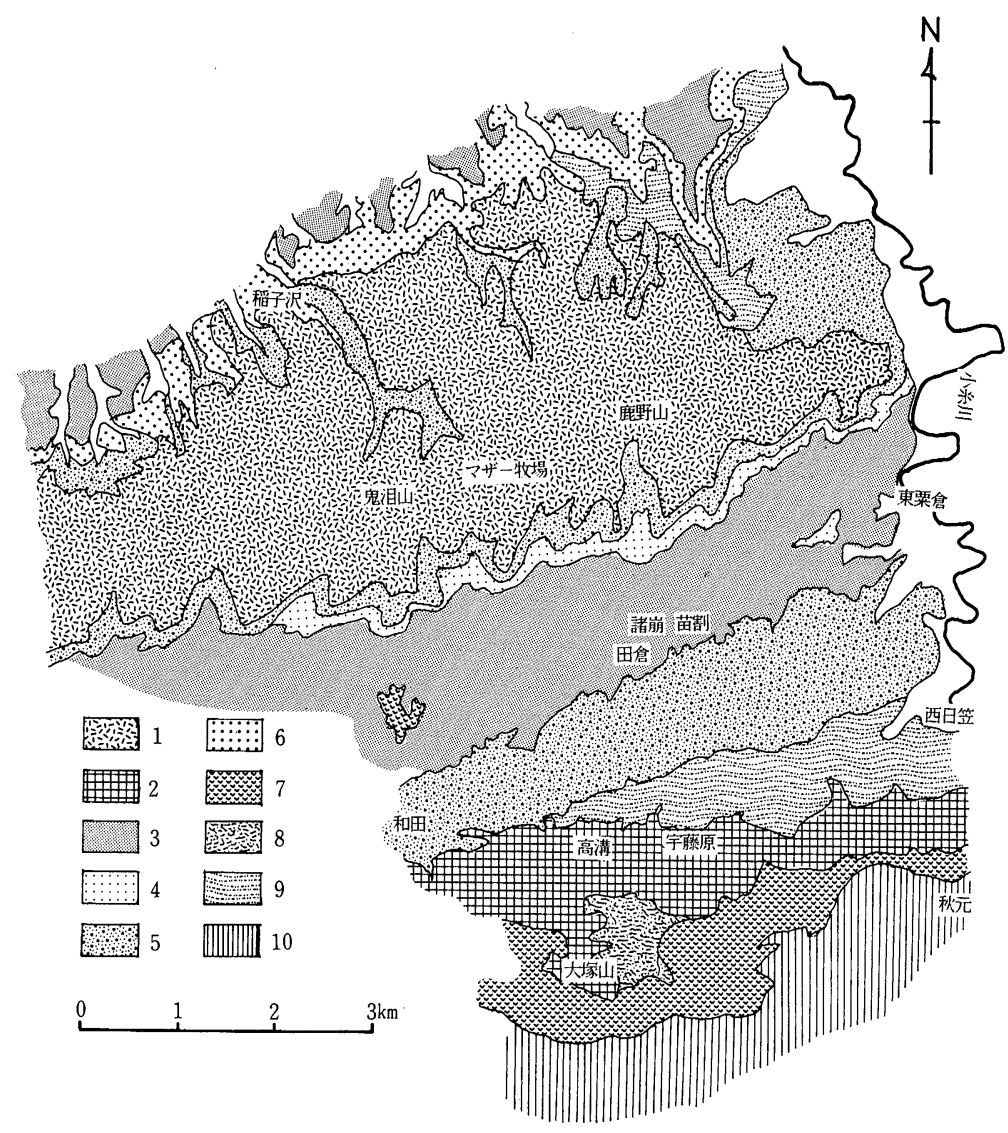

図－2 鹿野山・九十九谷と周辺地域の地質（地質調查所，1962; を簡略化）

1: ローム，2: 泥岩，3: 砂質泥岩・泥質砂岩，4: 細粒砂岩・中粒砂岩，5: 粗粒砂岩・ 含䃯砂岩, 6: 含砅砂岩・砅岩, 7: 凝灰質砂岩・凝灰質䃯岩, 8: 砂岩・泥岩互層 (異常堆積), 9: 泥岩・砂岩互層, 10: 安野砂岩・泥岩互層
九十九谷地域では谷底低地と平 坦面を除けば， $8^{\circ}$ 以下の傾斜分 布はほとんどない。起伏量や傾 斜分布のほか調査対象地域の地 形のもう一つの特徵を示す要素 に谷密度がある。調查地域の谷 密度と傾斜分布とは整合性があ り，以下，土地分類基本調查資 料（川崎ほか, 1976）より作成 した図 $-5,6$ の谷密度分布の特 徵をみると次のようになってい る。鹿野山の稜線に沿う部分は $1 \mathrm{~km}^{2}$ 当り谷密度 20 で, 調査対 象地域のうちでは低い谷密度地 域を示す。しかし，鹿野山の南 側斜面に沿っては, $1 \mathrm{~km}^{2}$ 当り 30 以上 50 に達する高谷密度地 域になる。また，鹿野山山塊の 北に広がる丘陵地帯は $1 \mathrm{~km}^{2}$ 当り 30 以上の谷密度分布地域 である。

一方, 鹿野山の南に広がる九 十九谷の地域は, 傾斜度 $20^{\circ}$ 以 下の地域が，割りと広く分布す る。それにもかかわらず，著し く高い谷密度分布地域になって いる図 $-5,6$ 。通常, 谷密度が 高ければ斜面の開析が進んだこ

A
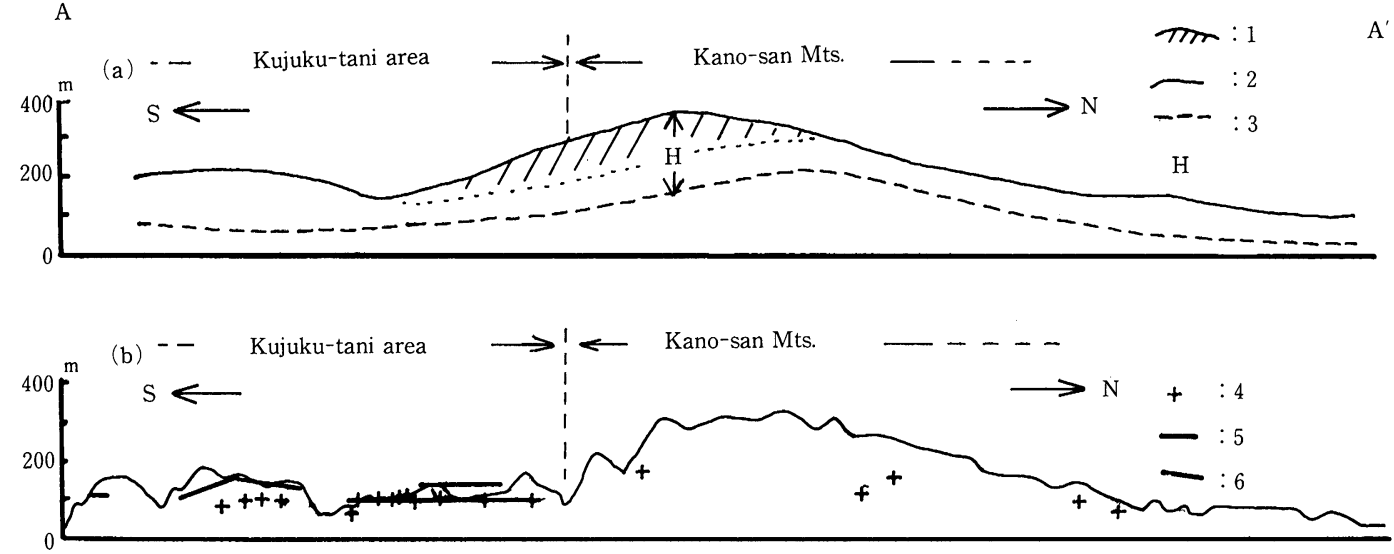

図ー3 鹿野山周辺山地の南北に切った地形面

(a)接峰面・切谷面による断面, (b) $1: 25,000$ 地形図による断面

$\mathrm{H}$ : 起伏量， 1 : 鹿野山北側斜面より余分な侵食土量，2：接峰面の断面，3: 切谷面の断面，4: 遷急点， 5 : 平坦面, 6 : 緩斜面 


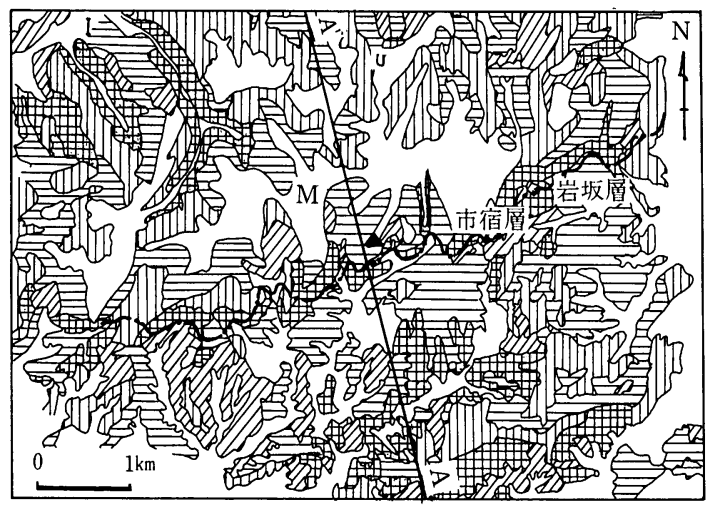

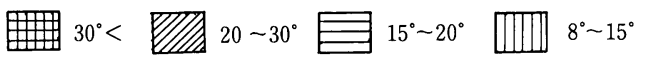

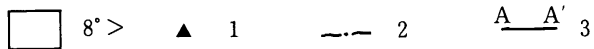

图-4 鹿野山と九十九谷周辺の傾斜分布 (千葉県, 1976 より) 1: 鹿野山の位置, 2: 市宿層と岩坂層の境界, 3: 図-3 地形断面図位置, M: マザー牧場, U: 馬登, I : 稲子 沢

土地分類基本調査（川崎ほか，1976）資料より作成

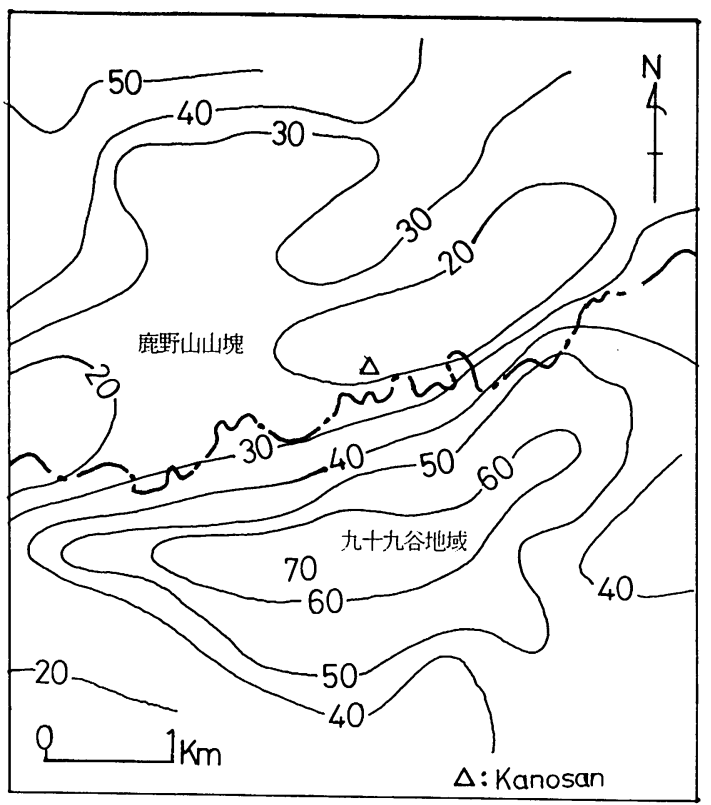

图-5 鹿野山周辺の谷密度分布

$\triangle:$ 鹿野山, - - - 市宿層と岩坂層の境界 土地分類基本調査資料（川崎ほか，1976）より作成

とを意味しているから，斜面は細分化し，谷に沿う斜面 は急傾斜を示すはずである。図一 4 の傾斜分布図は 1 / 50,000 の地形図を使用して作成されており，図作成時の 等高線の読取りは $20 \mathrm{~m}$ が限界であり, 九十九谷地域の ように, 低い山地で在りながら, 谷密度の高い地域の詳 細な傾斜度の表現は困難である。空中写真判読・現地調 査の結果では, この地域に発達する平坦面・緩斜面を除

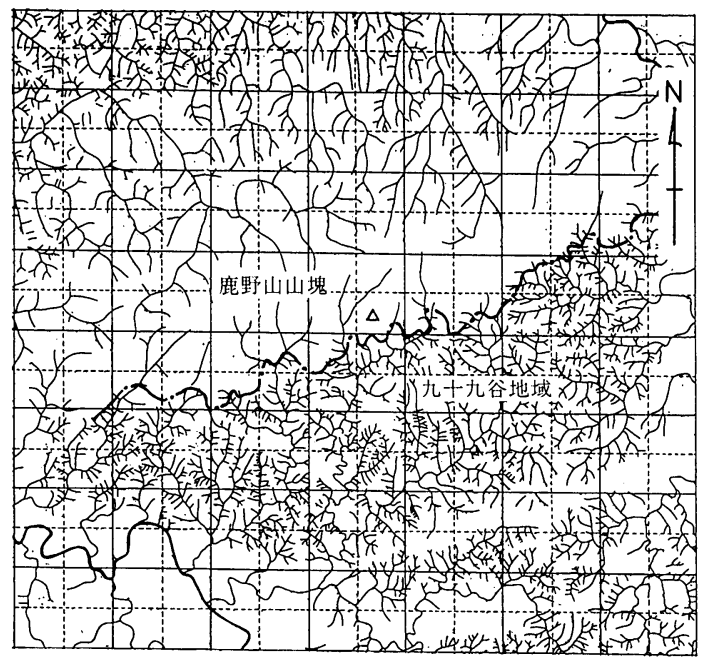

$\Delta \quad: 1 \quad-\cdot-: 2$

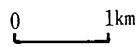

图－6＼cjkstart鹿野山周辺地域の水系分布（千葉県, 1976 より) 1: 鹿野山，2: 市宿層と岩坂層の境界

けば，斜面は小さい谷によって細分化され，それらの谷 に沿う山地斜面は, 地形図で読み取れる傾斜よりは著し く急になっている。また，この地域の平坦面・緩斜面の 下方は懸崖に近い急崖または急斜面をなし, 遷急点も 伴っていて, 斜面の傾斜変換線の存在を示している。

\section{3. 鹿野山・九十九谷および光の周辺の崩壊地 の分布}

本地域の崩壊現象は昭和 45 年, 46 年, 平成元年の 3 回 の豪雨に基づいている。昭和 45 年, 平成元年は前線性の 豪雨, 昭和 46 年は台風による豪雨である。このうち昭和 46 年の崩壊現象は豪雨をもたらした台風の経路が房総 半島東部にあったので, 調査地域ではごく軽微であった。 ここでは昭和 45 年と昭和 46 年発生の崩壊地の分布およ び平成元年発生の崩壊地の分布を, 昭和 45 年以前, 昭和 47 年, 平成元年 (8月 29 日) の各撮影年次の異なる空中 写真を用い, 崩壊地の判読を行い, 分布図図 $-7,8,9$ を 作成した。以下, 分布図図 $-7,8,9$ に従って述べる。

1) 昭和 45 年崩壊災害

昭和 45 年の崩壊災害は 7 月の梅雨前線の活動によっ て, 千葉県中〜南部の山間地に多発した。このうち千葉 県中部の鹿野山東部から大多喜に至る地域は, 昭和 46 年 の崩壊災害と重なり合う地域で, 平成元年次の崩壊現象 と比較するのに好都合であった。

昭和 45 年の崩壊地の分布は図 $-7 に$ 示されるように 万田野の北側の山地を除けば, 東粟倉から月崎を通る線 より南の山地に集中分布する。特に鹿野山南斜面, 大塚 山近傍, 上総松岡から大多喜に至る山地地域に密集地を 形成し，かつ東にいくほど密集の度合いが高くなる。 


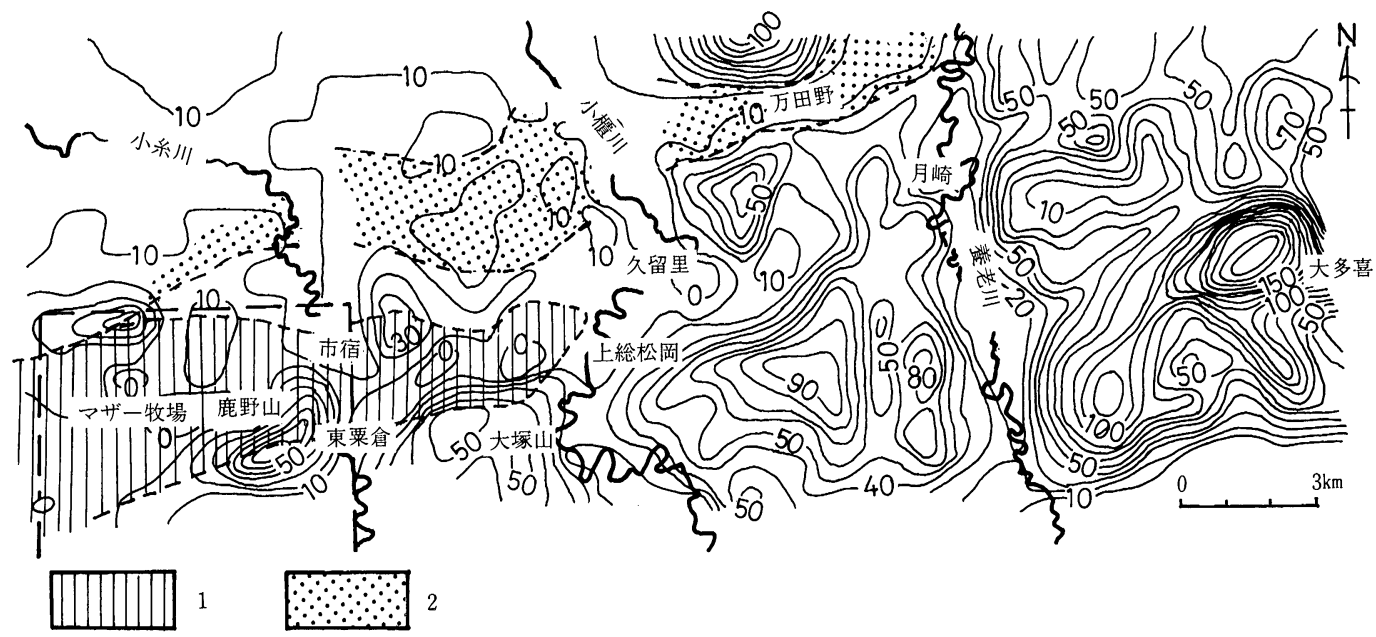

图-7 崩壊地の分布密度と地質分布の概要

枠は図一 $2 ， 4 \sim 6,8,9$ のおおよその位置，1: 砂層，2：礫層・含碟砂層

1989.8.1.

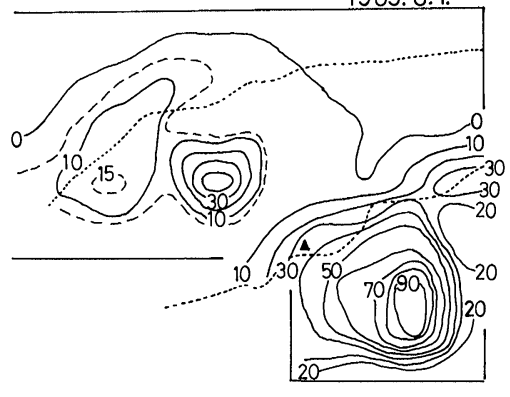

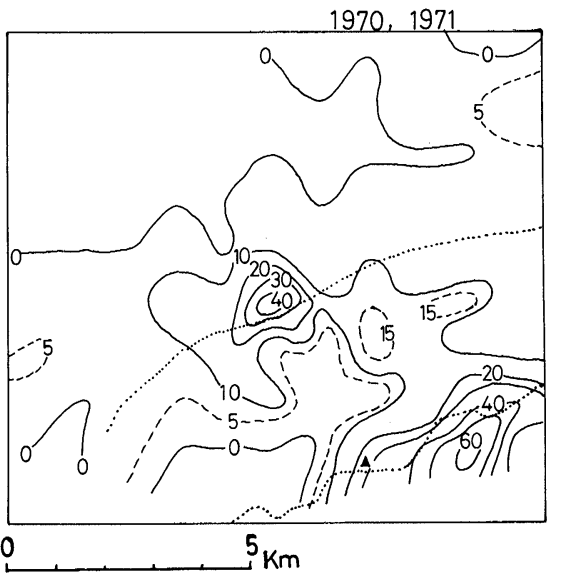

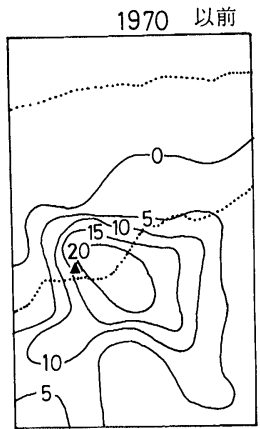

図-8 昭和 45 年 (1970) 以前, 45 年, 平成元年 (1989) の各 崩壊地の分布と砂層の分布する範囲（点線の範囲が市 宿層)

\section{a ）崩壊地と地形}

崩壊地と地形の関係は特に斜面の傾斜・傾斜変換点・ 谷密度が重要である。これは傾斜が増せば増すほど斜面 上の物質は不安定になり, また傾斜の変換は崩壊の誘引 となる水の導水勾配の変化に関係し, 谷密度は崩壊にか かわる集水能力と深く関わるからである。一般に崩壊地 の分布は傾斜度 $30^{\circ} \sim 40^{\circ}$, 高い谷密度の地域に多く, 傾斜 変換点の部分に集中する。図一7に見られる崩壊密集地 域は, 土地分類基本調査資料で千葉県の地形を検討する と次のようになる。

崩壊密集地は高傾斜度地域におおよそ一致する。しか し, 養老川以東の地域は $20^{\circ}$ 以下の傾斜度の分布が $2 / 3$ 以上に達し, 必ずしも傾斜度の高い地域となっていない が, 図一7に示されるように崩壊地の最も密集する地域

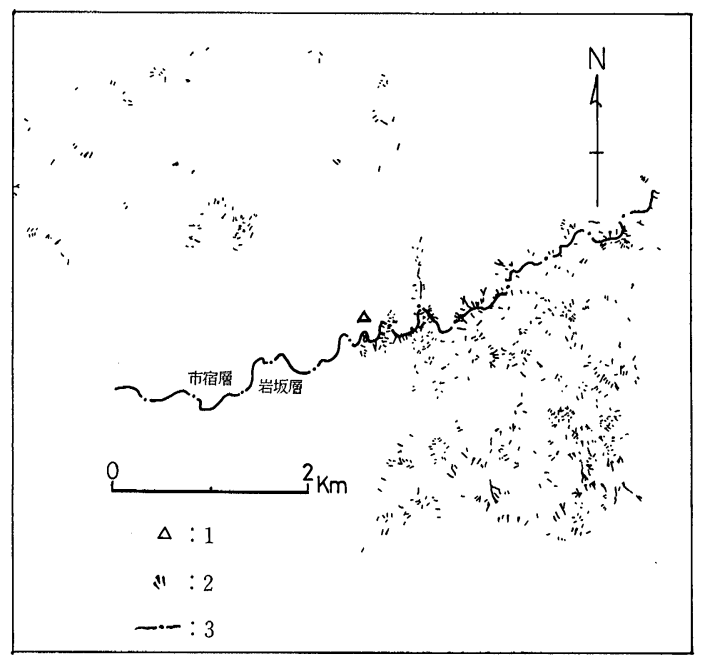

図-9 平成元年豪雨による鹿野山・九十九谷地域の崩壊地分 布，1: 鹿野山，2: 崩壊地，3: 市宿層と岩坂層の境界 
を形成している。一方，谷密度の分布は，東粟倉から久 留里の南を経て月崎を通る線から南側の地域に著しく高 くなっている。特に養老川の東側の山地は谷密度が高く, 谷の発達による山地斜面の細分化で土地分類基本調査資 料千葉県に示される傾斜分布の状態よりもより傾斜度が 高くなっていると考えられる。この傾斜分布と実際の傾 斜度の違いは，すでに記したように，傾斜分布図作成に 当たって $1 / 50,000$ 地形図を使用していることからくる 地形図の精度に原因していると考えられる。いずれにし ても, 高い傾斜度, 高い谷密度が崩壊発生に大きく関わっ ている。

b ）崩壊地と地質

既に示したように, 崩壊地と地質の関係を知るために, 崩壊地の密度分布と対象地域の主要な地質を併記した 図ー7が作成されている。それによれば, 主要な地層は市 宿層および長浜層の碟層, 含磜砂層である。図ー7で明ら かなように, 崩壊地と地質の関係は崩壊地の分布が極め て明瞭に砂層・碩層・含碩砂層の分布する地域に少なく なる。崩壊地の高密度分布地域は大部分砂質泥岩ないし 泥質砂岩, あるいはこれらの互層から構成されている。 昭和 45 年の崩壊災害の地形・地質の関係は以上のようで あり，崩壊地・傾斜分布・谷密度分布・地質はそれぞれ 互いに関係しあって, この地域の地形の発達に関わり, 崩壊現象はこの過程の重要な役割をはたしている。

\section{2 ) 平成元年崩壊災害}

平成元年 7 月 31 日から 8 月 1 日夜半にかけて降り続 いた衰雨（後述）によって，鹿野山南斜面から九十九谷 の山地地域, これより南の鋸山周辺の白狐川・相川の上 流域および保田川流域に崩壊災害が集中した。以下には これらの地域のうち, 鹿野山と九十九谷の周辺地域の崩 壊の特徵を取り上げる。

a ）崩壊地分布と地形・地質の関係

鹿野山・九十九谷地域は前述の昭和 45 年崩壊災害の一 部と 19 年後の平成元年の崩壊災害は重なり合い図 -7 参照, 崩壊災害の常習地の疑いがある。図 $-8,9$ で明ら かなように, 昭和 45 年以前, 45 年, 平成元年の崩壊地の 分布は, 鹿野山の南斜面から九十九谷の地域に広がる。 各時期による若干の分布の違いは認められるが，大勢は 大きく変わらない。それらは次のようである。

昭和 45 年以前の崩壊地の分布が鹿野山南斜面から九 十九谷の地域に限られていたのに対し, 昭和 45 年豪雨に 際しては鹿野山北斜面の馬登周辺地域にも多発が認めら れ，平成元年の崩壊現象はマザー牧場北西部に多発を 伴った。昭和 45 年の馬登周辺地域の崩壊地の分布は市宿 砂層の分布範囲外にあり，平成元年のそれは稲子沢付近 から市宿層を深く切り込む谷の部分に位置している。以 上を要約すると, 図 $-7,8$ に示される分布の最大の特徴
は，市宿層の分布する地域に崩壊が極めて少なくなるこ とである。さらに図ー7,8に示される崩壊地の分布のう ち最も西に位置する鹿野山周辺について特に取り上げ, 図-2，4，5，6，9 を作成し，比較考察した結果が以下の ようである。

この地域の地形は未固結の透水性のよい市宿層と固結 の進んだ岩坂層・東日笠層などの泥質岩・砂岩などから 構成される地域に区分した場合, 前者が起伏の大きい鹿 野山の山地, 後者が起伏の小さい九十九谷地域を形成し ている。これらの山地は谷の発達によって決定づけられ， 透水性の悪い地層からなる九十九谷地域に表面流として 谷の発達が著しく, 谷密度も高くなっている。あわせて 固結の進んだ地層からなる鹿野山南側斜面から九十九谷 の地域の, この谷の発達とあいまって, 急傾斜の地域が 広がる。崩壊地は上記の特徴である急傾斜面という不安 定性と, 谷のはたす集水機能によって鹿野山南側斜面, および九十九谷地域の急傾斜面・高谷密度地域に集中す る。特にマザー牧場の北西方の崩壊地の集中する部分は $30^{\circ}$ 以上の急傾斜面が発達し, これが原因する不安定地域 として説明できる。

以上に述べた崩壊・地形・地質の相互の関係は直接密 接に関連しあい, この地域の地形を成立させている。従 来，このような地質がきわめて明瞭に地形に反映されて いる地形を組織地形と呼び, この地域ではこの組織地形 形成に崩壊が主要な役割をはたしている。要するに, こ の地域では, 崩壞現象はこの組織地形形成と切り離せな い関係になっている。

b ）崩壊地分布と植生の関係

崩壊発生と深く関わりのある調査地域の植生状況に関 しては, 千葉県林務課作成の林相図がある。この林相図 を基に, 空中写真判読によって抽出した崩壊地とで表一 1 を作成した。作成した表ー1（a～c ）は植生を林齢と 樹種（杉，桧，その他）に分け，林齢・樹種別に崩壊地 数を数え上げ表示した。表ー1 (a)は林龄・樹種別の総崩壊 地数, 表 -1 (b)は林齢・樹種別植林面積, 表 -1 (c)は 1 ha 当りの林齢・樹種別植林面積に対する崩壊箇所数が示さ れている。表ー1 から単純にみれば, 林齢別崩壊数では 3 年生の部分に多く, 次いで 5 年生, 6 年生と続く。しか し, 1 ha 当りの崩壊地数では 6 年生に多く, 次いで 5 年 生, 3 年生の順になっている。いずれにしても崩壊地の大 部分が樹齢 10 年以内の幼齢林の地域や森林伐採地に集 中する。これは樹根による土層の緊縛効果や樹葉による 降雨の樹間遮断効果の排除の影響によるのであろう。

\section{4 、崩壊発生をもたらした降雨の特徵}

a ) 平成元年豪雨の推移

平成元年豪雨は前線通過と台風の影響によって平成元 


\begin{tabular}{|c|c|c|c|c|c|c|c|c|c|c|c|c|c|c|c|c|c|c|c|c|}
\hline $\begin{array}{l}\text { 林令 } \\
\text { 樹種 }\end{array}$ & 1 & 2 & 3 & 4 & 5 & 6 & 7 & 8 & 9 & 10 & 11 & 12 & 13 & 14 & 15 & 16 & 17 & 18 & 19 & 20 以上 \\
\hline 杉 & 11 & 5 & 21 & 6 & 9 & 7 & 6 & & 0 & & & & & & & 0 & & & & 12 \\
\hline 桧 & 8 & 3 & 12 & 4 & 16 & 15 & 2 & & 5 & 5 & & & & & & & 3 & & 3 & 13 \\
\hline その他雓木 & & & & & & & & & & & & & & & & & & & & 1 \\
\hline 計 & 19 & 8 & 33 & 10 & 25 & 22 & 8 & & 5 & 5 & & & & & & 0 & 3 & & 3 & 26 \\
\hline \multicolumn{21}{|c|}{ 面 積（植 林）（ha） } \\
\hline 杉 & 4.13 & 3.36 & 5.37 & 5.98 & 7.05 & 3.45 & 4.34 & & 0.97 & 0 & & & & & & 3.28 & 0 & & 0 & 11.43 \\
\hline 桧 & 3.35 & 3.36 & 2.26 & 2.87 & 0.94 & 6.16 & 1.86 & & 2.84 & 1.28 & & & & & & 0 & 9.26 & & 2.46 & 7.53 \\
\hline その他雍木 & 1.66 & 1.90 & 5.39 & 2.43 & 1.64 & 1.25 & 1.5 & & 0.44 & 0.83 & & & & & & 0 & 0.71 & & 0.6 & 13.77 \\
\hline 計 & 9.14 & 8.62 & 13.02 & 11.28 & 9.63 & 10.86 & 7.7 & & 4.25 & 2.11 & & & & & & & 9.97 & & 3.06 & 32.73 \\
\hline \multicolumn{21}{|c|}{ 面積に対する崩壊箇所数（1 ha 当り） } \\
\hline 杉 & 2.7 & 1.5 & 3.9 & 1.0 & 1.3 & 2.0 & 1.4 & & 0 & 0 & & & & & & 0 & & & & 1.0 \\
\hline 桧 & 2.4 & 0.9 & 5.3 & 1.4 & 17.0 & 2.4 & 1.1 & & 1.8 & 3.9 & & & & & & & 0.3 & & 1.2 & 1.7 \\
\hline その他䧴木 & & 0 & 0 & 0 & 0 & 0 & 0 & & 0 & 0 & & & & & & & & & & 0.1 \\
\hline 計 & 2.1 & 0.9 & 2.5 & 0.9 & 2.6 & 7.9 & 1.0 & & 1.2 & 2.4 & & & & & & 0 & 0.3 & & 1.0 & 0.8 \\
\hline
\end{tabular}

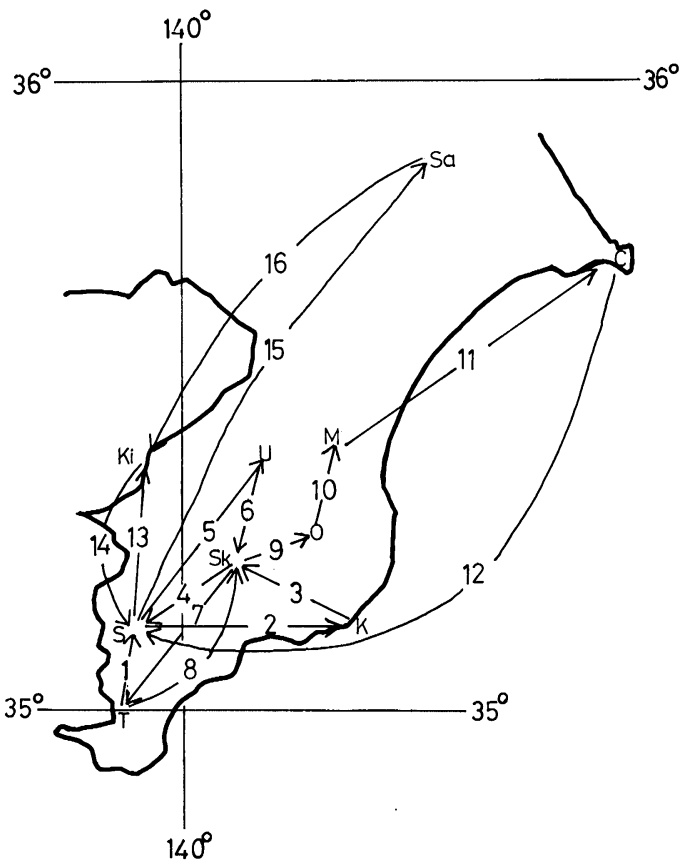

図-10 時間最大降雨量出現地点の分布 1〜16 は出現時間の順序

$\mathrm{T}$ : 館山, $\mathrm{S}$ : 佐久間, 勝浦, $\mathrm{S}_{\mathrm{k}}$ : 坂畑, $\mathrm{U}$ : 牛久, $\mathrm{O}:$ 大多喜, $\mathrm{M}$ : 茂原, $\mathrm{C}$ : 銚子, $\mathrm{K}$ : 木更津, $\mathrm{S}_{\mathrm{a}}$ : 佐 原

年 7 月 31 日午後から降り始めた。この雨は 31 日 22 時 20 分銚子地方気象台と館山測候所からそれぞれ県北部, 県北東部, 県南部に洪水・雷・波浪注意報が発せられ, 続いて 8 月 1 日 3 時 50 分に県南部地区に館山測候所か ら大雨・洪水鳘報，波浪注意報，同じく 8 月 1 日 5 時 10 分に県北西部，北東部に銚子地方気象台から大雨・洪水

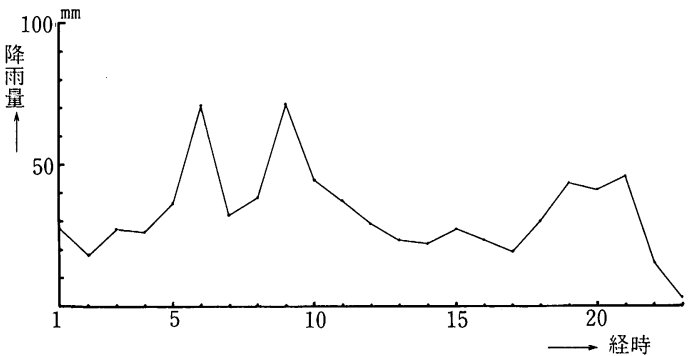

図-11 8 月 1 日の最大時間雨量の出現時刻の経時変化

警報が発せられ, 集中豪雨が確実となった。 8 月 1 日 0 時 からの県下に発現した時間雨量の最大値の推移を見ると, 館山で $27 \mathrm{~mm}$ が記録され, 時間と共に場所を変え, 佐久 間一勝浦一坂畑一佐久間・佐久間－牛久一坂畑一大多喜 (黒原) 一茂原一銚子一佐久間一木更津一佐久間一佐原一 木更津と推移した。

この豪雨の場所的経過は, 前半は佐久間・坂畑を中心 として, 後半は少し北へ移動し, 木更津が中心となって いる図 -10 。雨量の時間的推移は 5 時から 11 時と, 18 時 から 22 時に大きな山が出現し, 前半の 5 時から 6 時に, 佐久間で $71 \mathrm{~mm}, 8$ 時から 9 時に坂畑で $71 \mathrm{~mm}$ の極大 值が現れている図一11。後半は木更津で $46 \mathrm{~mm}$ が記録 され，恐らく山間部ではこれを上まわったと思われる。 聞き取りによれば，千葉県中部林業事務所管内の鬼泪山 では, 公式記録ではないが $90 \mathrm{~mm}$ を越えたという。降り 始めからの総雨量は, 佐久間の $445 \mathrm{~mm}$ が最大で, 坂畑 $385 \mathrm{~mm}$, 木更津 $310 \mathrm{~mm}$ であった。県下における各地の 総雨量の分布と, 時間最大雨量を表一 2 に示した。

以上の経緯から, 平成元年の集中豪雨の実態は各地に ゲリラ的に飛火しながら, 前半は鋸南町佐久間・君津市 
表 -2 平成元年 7 月 31 日 8 月 1 日の崩壊災害時の降雨状況 $(\mathrm{mm})$

\begin{tabular}{|c|c|c|c|c|c|c|c|c|c|c|c|c|c|c|c|c|c|c|c|c|c|c|c|c|c|c|c|}
\hline 測所名 & 13:00 & & & 2:00 & $3: 00$ & 4:00 & 5:00 & 6:00 & 7:00 & 8:00 & 9:00 & 10:00 & 11:00 & 12:00 & 13:00 & 14:00 & 15:00 & $16: 00$ & 17:00 1 & 18:00 & 19:00 & 20:00 & 21:00 2 & 22:00 & 23:00 2 & $24: 00$ & 総雨量 \\
\hline 佐原 & 1 & 0 & 1 & 1 & 0 & 2 & 3 & 4 & 6 & 14 & 8 & 5 & 7 & 19 & 9 & 9 & 5 & 7 & 0 & 11 & 43 & 18 & 4 & 4 & 1 & 0 & 173 \\
\hline 我孫子 & 2 & 0 & 1 & 0 & 1 & 6 & 1 & 4 & 2 & 1 & 7 & 7 & 6 & 6 & 5 & 8 & 10 & 9 & 4 & 6 & 1 & 0 & 2 & 9 & 2 & 0 & 104 \\
\hline 東庄 & 4 & 0 & 1 & 0 & 1 & 8 & 2 & 3 & 4 & 10 & 3 & 10 & 20 & 19 & 22 & 8 & 8 & 3 & 1 & 4 & 8 & 1 & 1 & 1 & 0 & 0 & 143 \\
\hline 船橋 & 1 & 0 & 2 & 1 & 6 & 7 & 1 & 2 & 4 & 4 & 5 & 5 & 4 & 6 & 6 & 8 & 12 & 11 & 7 & 2 & 1 & 0 & 23 & 0 & 1 & 0 & 133 \\
\hline 佐倉 & 0 & 0 & 1 & 2 & 0 & 6 & 4 & 4 & 4 & 4 & 3 & 3 & 6 & 7 & 10 & 9 & 8 & 2 & 2 & 5 & 1 & 3 & 9 & 10 & 0 & 3 & 102 \\
\hline 銚子 & 1 & 0 & 1 & 0 & 9 & 9 & 1 & 3 & 9 & 2 & 2 & 6 & 9 & 4 & 2 & 13 & 27 & 0 & 2 & 7 & 1 & 0 & 0 & 3 & 0 & 0 & 109 \\
\hline 横芝 & 1 & 0 & 6 & 0 & 0 & 4 & 3 & 6 & 5 & 8 & 3 & 13 & 28 & 12 & 8 & 5 & 13 & 1 & 7 & 9 & 16 & 2 & 3 & 0 & 0 & 0 & 158 \\
\hline 千葉 & 1 & 1 & 0 & 1 & 12 & 12 & 2 & 6 & 5 & 2 & 1 & 3 & 8 & 5 & 8 & 10 & 8 & 3 & 8 & 7 & 3 & 11 & 13 & 5 & 0 & 4 & 147 \\
\hline 茂原 & 1 & 0 & 0 & 4 & 6 & 2 & 3 & 6 & 18 & 22 & 29 & 14 & 20 & 11 & 10 & 22 & 3 & 1 & 3 & 20 & 0 & 0 & 1 & 0 & 1 & 0 & 210 \\
\hline 木更津 & 8 & 1 & 4 & 1 & 21 & 13 & 28 & 5 & 7 & 7 & 6 & 25 & 13 & 7 & 9 & 5 & 10 & 3 & 19 & 1 & 8 & 41 & 46 & 15 & 0 & 2 & 309 \\
\hline 牛久 & 1 & 1 & 0 & 1 & 14 & 4 & 12 & 17 & 32 & 34 & 13 & 27 & 17 & 9 & 17 & 11 & 3 & 1 & 7 & 1 & 14 & 9 & 2 & 0 & 3 & 0 & 265 \\
\hline 坂畑 & 4 & 2 & 1 & 1 & 12 & 26 & 14 & 2 & 19 & 38 & 71 & 44 & 35 & 29 & 16 & 6 & 2 & 7 & 18 & 7 & 13 & 3 & 0 & 0 & 0 & 0 & 382 \\
\hline 黒原 & 2 & 0 & 1 & 3 & 21 & 12 & 10 & 10 & 0 & 27 & 42 & 19 & 8 & 11 & 23 & 3 & 3 & 5 & 4 & 7 & 6 & 0 & 0 & 0 & 1 & 0 & 247 \\
\hline 佐久間 & 4 & 1 & 6 & 18 & 8 & 5 & 36 & 71 & 26 & 35 & 50 & 36 & 21 & 16 & 12 & 6 & 4 & 23 & 1 & 30 & 15 & 5 & 2 & 0 & 0 & 0 & 443 \\
\hline 鴨川 & 4 & 1 & 0 & 9 & 16 & 25 & 1 & 0 & 1 & 33 & 35 & 26 & 26 & 20 & 14 & 5 & 1 & 8 & 1 & 12 & 4 & 0 & 0 & 5 & 0 & 0 & 261 \\
\hline 勝浦 & 0 & 0 & 0 & 2 & 27 & 18 & 7 & 3 & 0 & 4 & 0 & 7 & 18 & 12 & 14 & 6 & 1 & 5 & 2 & 10 & 0 & 0 & 0 & 0 & 0 & 0 & 165 \\
\hline 館山 & 4 & 4 & 27 & 3 & 5 & 6 & 2 & 5 & 2 & 2 & 12 & 5 & 37 & 12 & 11 & 2 & 2 & 8 & 9 & 6 & 7 & 2 & 0 & 0 & 0 & 0 & 184 \\
\hline
\end{tabular}

坂畑が中心で, 後半は北の木更津に中心を移し終息した。 その結果, これらの集中豪雨の中心となった地域では山 地崩壊が多発し，昭和 45 年の災害より少なかったが，死 者 4 名, 重軽傷者 9 名を出す惨事となった。

なお, 昭和 45 年の豪雨の推移も, 場所的な違いはある が，前線性の豪雨であったので，類似のゲリラ的な降雨 状況にあったものと思われる。

\section{5.おわりに}

鹿野山周辺地域を対象に, 崩壊発生と地形・地質の関 係を調査した。その結果は以下のように要約される。

鹿野山から大多喜に至る山地地域では透水性のよい市 宿層の砂層や長浜層の砂䃯層で斜面の傾斜度が小さく, 崩壊発生が著しく少なくなっている。これに比して, 岩 坂層・粟倉層・東日笠層・国本層など半固結ないし，固 結し透水性の悪い地層に崩壊が多発している。また，後 者の泥質岩の地域は谷の発達が良く, 谷密度が高く, 急 斜面になっている。特に鹿野山南斜面では，透水性の良 い市宿層とその下にある透水性の悪い岩坂層の境付近に 崩壊が集中した。要するに, この地域の地形は地層の透 水性を主な成因とする組織地形（差別侵蝕地形）を形成 していて, この過程で崩壊が深く関係し, 崩壊発生に常
習的傾向をもたらす結果となっている。なお，鹿野山山 塊の火山灰層の被覆状況から, この地域の地形の概形は 火山灰降灰以前にほほ決定されたものと思われる。

崩壊発生の原因で，地形・地質以外に見落とせないの が植生である。千葉県中部林業事務所管内の林相図から 森林伐採跡地・幼踚林に多く発生することがわかった。

\section{謝 辞}

この調査研究を実施するに当たって, 千葉県林務課お よび中部林業事務所に大変お世話になった。記して謝意 を表する。

\section{参考文献}

1）地質調查所 (1962)：1/10万地質図 東京湾とその周辺地 域の地質

2 ）三梨 昂 (1954): 房総半島鬼泪山南部の地質一特に岩相 の時空的ひろがりについてー，地質学雑誌，第60巻，第 710 号, pp. 461 472.

3 ) Nakagawa H. (1960): On the cuesta topography of the Boso Peninsula, Chiba Prefecture, Japan. Sci. Rept. Tohoku Univ., Ser II (Geol. ), Sepec. Vol. 4, pp. $385 \sim 391$.

4 ）川崎逸郎ほか（1976）：1/5万土地分類基本調查 富津 千葉県

6）川崎逸郎ほか (1976)：1/5万土地分類基本調查 大多喜 千葉県

（原稿受理日＼cjkstart平成3年12月21日） 